\title{
Transvaginal Cystocele Repair Using Tension-free Polypropylene Mesh (Tension-free Vaginal Tape)
}

\author{
LAVINIA STELEA ${ }^{1 *}$, VERONICA DANIELA CHIRIAC ${ }^{1 *}$, MARIUS CRAINA ${ }^{1}$, IZABELLA PETRE $^{1 *}$, ZORAN POPA ${ }^{1 *}$, BRIGITHA VLAICU2\#, \\ DANIELA IACOB ${ }^{3}$, LAVINIA CRISTINA MOLERIU ${ }^{4}$, MIHAELA VIVIANA IVAN ${ }^{5 *}$, ELENA POP ${ }^{6}$, LAZAR FULGER ${ }^{7}$ \\ ${ }^{1}$ Victor Babes University of Medicine and Pharmacy, Discipline of Obstetrics-Gynecology III, Department XII, 2 Eftimie Murgu \\ Sq., 300041, Timisoara, Romania \\ ${ }^{2}$ Victor Babes University of Medicine and Pharmacy, Department XIV Microbiology, Discipline of Hygiene, 2 Eftimie Murgu Sq., \\ 300041,Timisoara, Romasnia \\ ${ }^{3}$ Victor Babes University of Medicine and Pharmacy, Department XIII, Discipline of Neonatology, 2 Eftimie Murgu Sq., 300041, \\ Timisoara, Romania \\ ${ }^{4}$ Victor Babes University of Medicine and Pharmacy, Department III of Medical Informatics and Biostatistics Victor Babes, \\ 2 Eftimie Murgu Sq., 300041, Timisoara, Romania \\ ${ }^{5}$ Victor Babes University of Medicine and Pharmacy, Cardiology Department, County Hospital Pius Brinzeu, 2 Eftimie Murgu Sq., \\ 300041, Timisoara, Romania \\ ${ }^{6}$ Victor Babes University of Medicine and Pharmacy, Department of Anatomy and Embryology, 2 Eftimie Murgu Sq., 300041, \\ Timisoara, Romania \\ ${ }^{7}$ Victor Babes University of Medicine and Pharmacy, Surgery Department, 2 Eftimie Murgu Sq., 300041, Timisoara
}

\begin{abstract}
Urinary incontinence is one of the most common diseases, $25 \%$ of women between 18 and 80 years suffer from it. Urinary incontinence can be described as accidently loss of small amounts of urine. The solution involves a surgical procedure, such as sling procedures and bladder neck suspension procedures. The methods of surgical interventions have evolved due to a minimum period of hospitalization (sling, TVT), or performing laparoscopic surgery instead of the classical Burch surgery. Studies reviled that the most effective interventions are those which restore the urethra by retro pubic urethropexy, pubovaginal sling and synthetic mid-urethral slings. This type of surgery has currently the highest success rate $185-90 \%$ on 5 years after surgery), and the lowest relapse rate. In our study we obtained the same success rate for the TVT procedure.
\end{abstract}

Keywords: urinary incontinence, tension-free vaginal tape (TVT), laparoscopic surgery

Currently there are more than $25 \%$ of women aged between 18-80 years who suffer from urinary incontinence. In reality the number of women who are suffering from urinary incontinence is much higher because many of them are reluctant to seek medical attention considering it as a disability, a natural consequence of childbirth. Urinary incontinence is defined as accidently loss of small amounts of urine, which exits the bladder through the urethra during activities or the urge to urinate that cannot be mastered by one's own will.

The International Continence Society (I.C.S.) classifies the urinary incontinence, based on etiology, into stress urinary incontinence, urge urinary incontinence and mixed urinary incontinence. Stress urinary incontinence is the leaking of small amounts of urine during activities. There is a simple stress urinary incontinence when occurs sometimes during a workout (fitness). The moderate stress urinary incontinence occurs during physical activities such as: standing up from a sitting position, laughing, sneezing, coughing, etc. Stress urinary incontinence is considered severe when uncontrolled leakage of urine from the bladder is becoming permanent. It is very important the appreciation of the patient for the seriousness of this medical problem [1-3].

Surgical solutions, such as sling procedures and bladder neck suspension procedures that are frequently chosen as a first method of treatment. The methods of surgical interventions have evolved due to a minimum period of hospitalization (sling, TVT), or performing laparoscopic surgery instead of the classical surgery (Burch) [4,5]. They offer variable favorable results, so that $70-90 \%$ of patients do not lose urine during the first year after surgery. These results, however, alters every passing year from the surgery [6-8].

Many studies have shown that polypropylene is a welltolerated synthetic material by the body, with little exposure of the patient to infection and vaginal or urethral erosion. Because they are expensive materials, many surgeons have long been used autologous grafts harvested from the rectus fascia and fascia late. They have the advantage of not being rejected by the body, so there is a lower rate of erosion and a possible infection can be treated with antibiotics. But the implant procedure leads to a longer hospitalization time; after the surgical procedure, there might be unaesthetic scars and therefore this procedure is not easily accepted, especially by young women $[9,10]$.

\section{Experimental part}

Material and method

In the present prospective study, we have introduced a number of 66 patients with stress urinary incontinence, cystocele or other forms of genital prolapse, which is the consequence of the change, in all cases, of the angle of the urethra beside the bladder neck. The patients were operated in Timisoara County Emergency Clinical Hospital - the Department of Obstetrics and Gynecology in the year 2017. In these patients, we placed, through a surgical procedure, in the hammock position, a mesh with two fixation arms using inside-out and outside-in trans-obturator sling.

\footnotetext{
* emaiul: danielachiriac98@yahoo.com; Phone: 004-0722 379832 dr.petreizabella@yahoo.com; Phone:004-0722646058;
}

\# Autors with equal contribution 
Sub-urethral tape (TVT) are in a continuous change, and, in terms of its composition, there were used, over time, a great variety of materials. According to Einhoernings's theory, the mechanism of action of these tapes is different compared to the traditional sub-urethral sling operations which consisted in bladder neck needle suspension with sub-urethral slings (fig. 1). Literature indicates that the tape is not a risk factor and improves significantly the ability to treat detrusor instability [11-13].

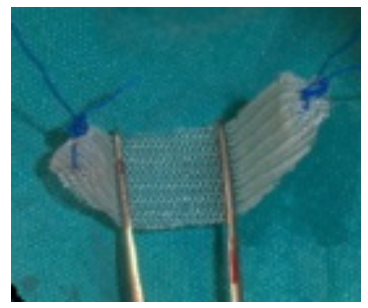

Fig. 1. Sub-urethral tape (TVT) used in our studied group of patients

The TVT procedure was introduced by Ulmsteen in 1995 and the IVS procedure was introduced by Petros (intravaginal slingplasty) in 2002 [14, 15]. The polypropylene tapes used in the TVT are monofilament. Their size is about $40 \mathrm{~cm}$ long and $1 \mathrm{~cm}$ wide. By fitting such polypropylene prosthesis or tapes there are created curable pubourethral neoligament, due to the deposition of collagen which forms an artificial neoligament according to Petros' theory [16-18]. The tapes activate the fibroblasts that are creating collagen deposition and forming therefore neoligaments. Anus lifters and endopelvic fascia are not perforated during the procedure. The device used to implant a polypropylene tape is passing through the anterior recess of the ischiorectal fossa that extend above the perineal membrane (the terminal branches of the pudendal nerve is under the perineal aponeurosis) limited by the anal sphincter muscles and medial side of the obturator internal muscles [9, 19].

For the statistical calculus we used the Microsoft Excel software.

\section{Results and discussions}

In order to have a complete picture of our sample we made some statistical calculus and we plotted the outcoming results.

The age distribution is presented in table 1 and plotted in figure 2.

There was a peak incidence ( 28 patients) in the 61 up to 70 year old age group (42.42\%). The mean age of the patients that were operated was 62.73 years old, and the extreme ages of our patients were 42 and 78 years old.

\begin{tabular}{|l|c|l|}
\hline Age group & $\begin{array}{c}\text { Number of } \\
\text { patients }\end{array}$ & $\%$ \\
\hline 41-50 years & 8 & $12.12 \%$ \\
\hline 51-60 years & 24 & $36.36 \%$ \\
\hline 61-70 years & 28 & $42.42 \%$ \\
\hline 71-80 years & 6 & $9.09 \%$ \\
\hline
\end{tabular}

Table 1

THE AGE

DISTRIBUTION

A number of factors are associated with the development of SUI. Therefore: childbirth - it is possible that during a vaginal delivery structures that make up the pelvic floor may become tautand tense when overworked; after birth they will not recover completely, giving a lower support of reproductive organs, urinary tract.

Because one of the major causes is the presence of childbirth we grouped our patients based on the following criteria, patients who didn't have children (nulliparous), patients who had one birth (primiparous) and patients who had at least two births (multiparous). It is noticed the fact that the multiparous patients (65.15\%) are predominant. This distributions are presented in table 2 and plotted in figure 3.

\begin{tabular}{|l|c|c|}
\hline Parity & $\begin{array}{c}\text { Number } \\
\text { of patients }\end{array}$ & \multicolumn{1}{l|}{$\%$} \\
\hline Nulliparous & 4 & $6.06 \%$ \\
\hline Primiparous & 19 & $28.79 \%$ \\
\hline Multiparous & 43 & $65.15 \%$ \\
\hline
\end{tabular}

Table 2

PATIENT'S DISTRIBUTION DEPENDING ON THE PARITY

We also, wanted to observe the medical records of our patients and their medical history. As their obstetrical history, their history of gynecologic surgery (ACG), their hormonal status, their urogenital symptoms, their sexual activity and their body mass index (BMI). In the first class we have only 62 patients because 4 patients did not give birth. All of the patients from our sample suffered at list one surgery. Menopause, along with the diminished expression of estrogen receptors induce a rapid weakening of the pelvic floor fascia. So, the pelvic floor fascia loses their strength and elasticity, this symptoms often are occurring or exacerbating along with the menopause. 62 patients (93.94\%) had undergone natural menopause. Regarding the patients distribution according to their urogenital symptoms on the doctor's visit we can say that the predominant problem consists in the presence of pelvic pain $(49.46 \%)$. Another known risk factor is the presence of obesity. In the presence of obesity the pressure on the pelvic floor increases with every extra kilogram of body
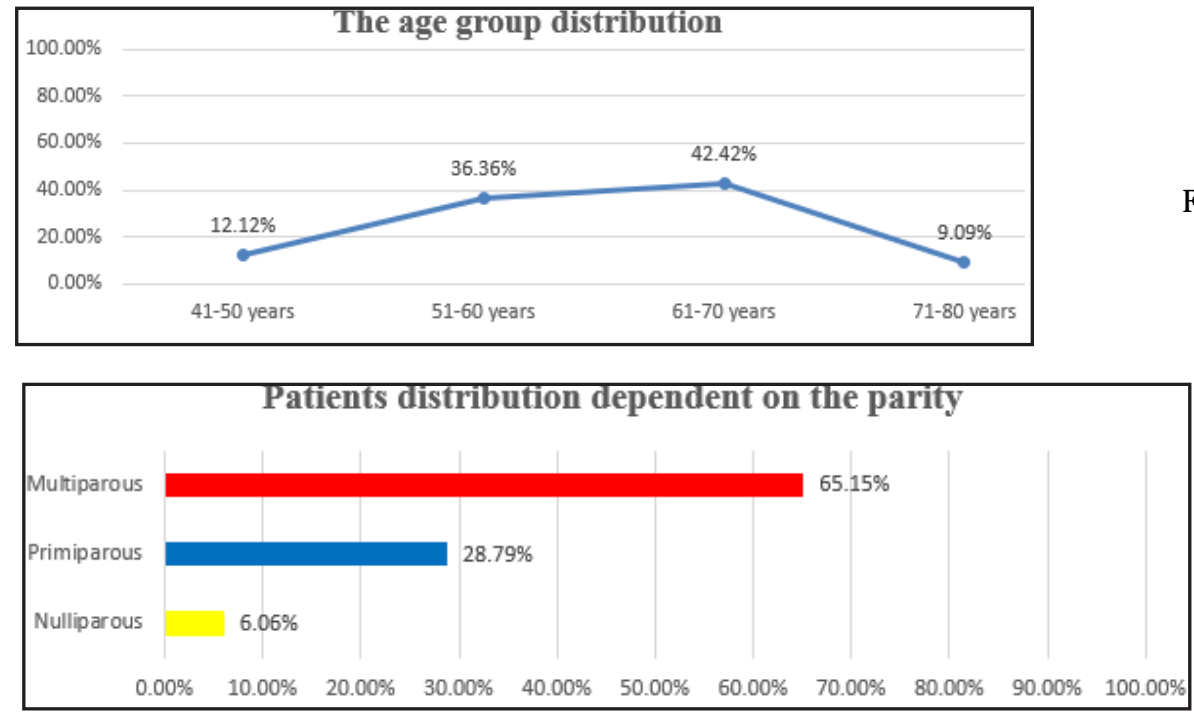

Fig. 2. The plot of the age group distribution

Fig. 3. The plot of the distribution depending on the parity 


\begin{tabular}{|c|c|c|c|}
\hline \multicolumn{2}{|c|}{ Medical problems } & $\begin{array}{c}\text { Number of } \\
\text { patients }\end{array}$ & $\%$ \\
\hline \multirow{2}{*}{ Obstetrical history } & Caesarean section & 8 & $12.90 \%$ \\
\hline & Vaginal delivery & 54 & $87.10 \%$ \\
\hline \multirow{5}{*}{$\begin{array}{l}\text { History of gynecologic } \\
\text { surgery }\end{array}$} & Vaginal hysterectomy & 22 & $33.33 \%$ \\
\hline & Anterior colpoperineorrhaphy & 9 & $13.64 \%$ \\
\hline & Posterior colpoperineorrhaphy & 6 & $9.09 \%$ \\
\hline & Burch colposuspension & 3 & $4.55 \%$ \\
\hline & Another surgery & 26 & $39.39 \%$ \\
\hline \multirow{2}{*}{ Hormonal status } & Natural menopause & 62 & $93.94 \%$ \\
\hline & Induced menopause & 4 & $6.06 \%$ \\
\hline \multirow{3}{*}{ Urogenital symptoms } & Lower urinary tract symptoms & 29 & $31.18 \%$ \\
\hline & Pelvic pain & 46 & $49.46 \%$ \\
\hline & Dyspareunia & 18 & $19.35 \%$ \\
\hline \multirow{2}{*}{ Sexual activity } & Sexual active & 26 & $39.39 \%$ \\
\hline & Sexual inactive & 40 & $60.61 \%$ \\
\hline \multirow{4}{*}{ Body mass index (BMI) } & Underweight, $\mathrm{BMI} \leq 18.5$ & 2 & $3.03 \%$ \\
\hline & Normal weight, BMI 18.5-24.9 & 24 & $36.36 \%$ \\
\hline & Overweight, BMI 25-29.9 & 36 & $54.55 \%$ \\
\hline & Obese, $\mathrm{BMI} \geq 304$ & 4 & $6.06 \%$ \\
\hline
\end{tabular}

Table 3

THE MEDICAL HISTORY OF OUR PATIENTS mass. Studies show that overweight women are more than twice as likely to have a risk to develop SUI compared to normal weight women or underweight women [20]. All the data are presented in table 3.

In the studied group 54 patients (34.61\%) were suffering from diseases such as diabetes mellitus (12 patients), noninsulin-dependent diabetes (11 patients), hypertension (44 patients), hypothyroidism ( 6 patients), and renal disease (3 patients). In the gynecological section we offer special attention to patients who have chronic renal insufficiency in the family and who have a undergoing dialysis program [4].

\section{Conclusions}

Surgery remains the treatment with the best cure rate and the lowest relapse rate. Although, over the years, many methods have been devised to correct stress urinary incontinence, studies show now that the most effective interventions are those which restore the urethra by retropubic urethropexy, pubovaginal sling and synthetic mid-urethral slings. This type of surgery has currently the highest success rate (85-90\% on 5 years after surgery), and the lowest relapse rate. As well, the medical reports which come from our study reveal the same success rate for the TVT medical procedure.

\section{References}

1.N. CALOMFIRESCU, A.V. MANU-MARIN, Urodinamica si Neurourologie. Editura Academiei Romane, 2004. ISBN: 973-27-11094.

2.N. CALOMFIRESCU, V AMBERT, A.V. MANU-MARIN, Incontinenta Urinara, diagnostic si terapie. Editura Medicala, 2011. ISBN: 978-97339-0707-7

3.MCKENZIE S, WATSON T, THOMPSON J et al: Stress urinary incontinence is highly prevalent in recreationally active women attending gyms or exercise classes. Int Urogynecol J 2016;27:1175. 4.PANTEA S., LUCHIAN G., CORINA PANTEA, F. LAZAR, D. BORDOS, M. PAPURICA, CARMEN BALASA-GURAGATA, S. NICOARA, ANCA MATES, The placement of Tenckhoff peritoneal dialysis catheter by laparoscopic approach, Chirurgia, Vol 103, Issue:6, pages 669-672; Published: Nov Dec 2008.

5.S. PANTEA, C. DUTA, I. SARGAN, F. LAZAR F, M. PAPURICA, C. BALASAGURAGATA, D. BORDOS, Histerectomia totala vaginala asistata laparoscopic cu evidare ganglionara pentru cancer de col incipient tehnicã operatorie. Chirurgia, (2011) 106: 365-368, Nr. 3, Mai - Iunie, ISSN 1221-9118, ISSN on line 184

6.ZIMMERN PE, GORMLEY E, STODDARD AM et al: Management of recurrent stress urinary incontinence after burch and sling procedures. Neurourol Urodyn 2016; 35:344.

7.WADIE BS AND ELHEFNAWY AS: TVT versus TOT, 2-year prospective randomized study. World J Urol 2013; 31:645

8.WALTER AJ, MORSE AN, HAMMER RH, HENTZ JG, MAGRINA JF, CORNELLA JL, MAGTIBAY PM. Laparoscopic versus open Burch retropubic urethropexy: comparison of morbidity and costs when performed with concurrent vaginal prolapse repairs. Am J Obstet Gynecol 2002; 186:723-728.

9.KUUVA N, NILSSON CG. A nationwide analysis of complications associated with the tension-free vaginal tape (TVT) procedure. Acta Obstet Gynecol Scand 2002; 81:72-77.

10.ROSITA ANIULIENË, SONATA BARILIENE, New surgicaltechnique for the treatment of urinary incontinence in Clinic of Obstetrics and Gynecology of Kaunas University of Medicine, Medicina (Kaunas) 2006; 42(9).

11.BORTOLOTTI A, BERNARDINI B, COLLI E. Prevalence and risk factors for urinary incontinence in Italy. Eur Urol $2000 ; 37: 30-35$.

12.ABRAMS P, CARDOZO L, FALL M, GRIFFITHSD, ROSIER P ULMSTEN U, VAN KERREBROECK PH, VICTOR A, WEIN A. The standardization of terminology of lower urinary tract function. Neurourol Urodynam 2002; 21: 167-178.

13.LAGRO-JANSSEN, SMITS AJA, VAN WEEL C. Women with urinary incontinence: self perceived worries and general practitioners' of knowledge of the problem. Br J Gen Pract 1990; 40: 331-334.

14.ULMSTEN U, PETROS P. Intravaginal slingplasty (IVS): an ambulatory surgical procedure for treatment of female urinary incontinence. Scand J Urol Nephrol 1995; 29:75-82.

15.MANU-MARIN AV, CALOMFIRESCU N, NEAMTU M: Investigarea tulburarilor mictionale. Rolul examenului urodinamic. Tendinte actuale de diagnostic si tratament in practica medicala. Editura Ministerului de Interne 2002; 405 . 
16.PETROS PE, ULMSTEN UI: An integral theory and its method for the diagnosis and management of female urinary incontinence. Scand J Urol Nephrol Suppl. 1993; 153: 1-93

17.PAULO PALMA, CASSIO RICCETTO, ROGERIO FRAGA, RICARDO MIYAOKA, ADILSON PRANDO, Dynamic Evaluation of Pelvic Floor Reconstructive Surgery Using Radiopaque Meshes and Threedimensional Helical CT, International Braz J Urol, Vol. 36 (2): 209-217, March - April, 2010

18.M. SERATI, S. SALVATORE, S. UCCELLA, W. ARTIBANI, G. NOVARA, L. CARDOZO et al Surgical treatment of female stress urinary incontinence. What is the gold standard procedure?Int Urologynecol J Pelvic Floor Dysfunction, 20 (2009), pp. 619-621
19.P. ABRAMS, K.E. ANDERSSON, L. BIRDER, L. BRUBAKER, L. CARDOZO, C.CHAPPLE, et al. Fourth International Consultation on Incontinence Recommendations of the International Scientific Committee: Evaluation and treatment of urinary incontinence, pelvic organ prolapse, and fecal incontinence, Neurourol Urodyn, 29 (2010), pp. $213-240$

20.INES M. LASO-GARCIA, MIGUEL A. RODRÍGUEZ-CABELLO, MIGUEL A. JIMÉNEZ-CIDRE, ANDREA OROSA-ANDRADA, DAVID CARRACEDOCALVO, LUIS LOPEZ-FANDO, FRANCISCO J. BURGOS-REVILLA, Prospective long-term results, complications and risk factors in pelvic organ prolapse treatment with vaginal mesh, European Journal of Obstetrics \& Gynecology and Reproductive Biology 211 (2017) 62-67

Manuscript reeived: 21.01 .2018 